\title{
Instructional leadership, Progressive Professional Development, Work Motivation, and the Assessment Results of Elementary School Teacher Competency
}

\author{
Tutik Kristiani *, Ahmad Suriansyah, Metroyadi \\ Master Program of Educational Management, Universitas Lambung Mangkurat, Banjarmasin 70123, \\ Indonesia
}

Article history:

Submission December 2019

Revised May 2020

Accepted May 2020

*Corresponding author:

E-mail: tutik.kristiani@gmail.com

\begin{abstract}
The purpose of this research is to describe and analyze the relationship between instructional leadership, progressive professional development, work motivation, and the results of elementary school teacher competency tests. The sample number of 120 was obtained by Proportional Random Sampling from 172 people in 22 schools at Binuang District. Data was collected using questionnaires that had passed validity and reliability tests. It was then analyzed by the product-moment correlation. The results obtained indicated a strong correlation between instructional leadership, continuing professional development, and work motivation about teacher competency test results. This research is expected to enhance teacher development and in further studies to improve education. Furthermore, it could be used by the teachers as an evaluation material, and as feedback for refinement and improvement of their ability and delivery. Also, information from this document could be used by the school principal to foster a good working environment for teachers. With good guidance, teachers would be competent enough to improve the learners' achievement. Additionally, this research provides the education stakeholders information which could be used in decision making to foster the teaching profession to achieve set goals and the quality of learning. And, it could be utilized as a reference document in future researches regarding the same subject matter.
\end{abstract}

Keywords: Instructional leadership, work motivation, assessment result, elementary school, teacher, competency

\section{Introduction}

The management of activities in the classroom and school is mostly done by teachers. when, the performance of the teacher is unsatisfactory for both the parents and students, it into something interesting to analyze the cause This was derived from an interview with the parties. It was further revealed that incomplete teaching and learning materials provided a challenge, though they are supposed to be prepared before the lesson. These challenges need to be solved to realize the set objectives. Instructional leadership helps straighten and keep the human resource accountable and competent. Effective and optimal leadership leads to the realization and achievement of school goals. School principals need to possess leadership skills to enhance competency in the learning institution (instructional leadership or for improved learning).

Instructional leadership focuses its emphasis on learning. Soutworth (2002) argued it is a strong determinant in teaching and learning processes. Effective learning strategies are as

How to cite:

Kristiani, T., Suriansyah, A., \& Metroyadi. (2019). Instructional leadership, progressive professional development, work motivation, and the assessmen results of elementary school teacher competency. Journal of K6, Education, and Management, 2 (3), 234 - 241. doi: 10.11594/jk6em.02.03.08 
follows: (1) modeling; (2) monitoring; (3) professional dialogue and discussion. Teacher performance needs to be monitored and used for further training. The professional discussion implies talking actively, interactively, effectively assertively, inspiratively, productively, democratically and scientifically about feedback from appraisals and follow-up plans to improve the quality of the process and student learning outcomes (Soutworth, 2002). Instructional leadership components include curriculum, teaching and learning process, assessment, teacher development, education, and restructuring of the school environment.

According to Halinger (2010), instructional leadership seems to have reincarnated into a new form broadly known as leadership for learning. The instructional leader's role in defining a clear mission. First, it was written down and visible around the school. Second, it focused on academic development appropriate to the needs of this particular school population. Third, the mission sets a priority for the work of teachers. Fourth, accepted legitimate by teachers throughout the school. Fifth, the mission was articulated, actively supported, and modeled by the principal.

Contrary to instructional leadership to improve competence, teachers need to grow themselves through continuous professional development (PKB) activities. it enhances the fulfillment of needs and improves professional practice. It has the way every member of a professional association maintains, refines, expands knowledge and skills, and develops the qualities needed in professional life. PKB has individual ideas aimed at increasing professional skills and knowledge. This opinion in line Labaree (2005) progressive pedagogy capitalizes on the needs and interests of the students to teach transferrable skills through engagement in self-guides learning. Educators accomplish this by incorporating projects "that integrate the disciplines around socially relevant democratic equality". Another research by Gambone (2017) that style or attitudes that progressive educators are to take up as they address issues of social justice in their school and with their students. Continuous professional development activity is aimed at increasing teacher competency. These activities include self-development, scientific publications, and innovative work. Through CPD, teachers could fulfill the standards and develop proficiencies, therefore being able to deal with internal and external changes in instructional duties. Teaching and learning activities are anchored on the educator. However, they need to be balanced by the instructional leader in charge. This boosts their morale hence, able to work effectively and efficiently. Work drive enhances the direction of the teacher's energy to the right goals. Therefore, concluded, the low work motivation of teachers impacts negatively on work results. leadership learning means the ability to motivate the work of subordinates, hence improving their enthusiasm for performing their duties.

Instructional leadership focusing on improving the quality of student learning is tested through a system implemented by the government. teacher quality control through Teacher Competency Test (UKG). The government carries out analysis and improvement in the implementation of education to increase teacher professionalism. According to Blasé and Blasé that principals can use six strategies to promote teachers' professional growth including (1) emphasizing the study of the teaching of teaching and learning; (2) supporting collaboration efforts among educators; (3) developing coaching relationships among educators; (4) encouraging and supporting the redesign of programs; (5) applying the principles of adult learning, growth, and development to all phases of staff development; (6) implementing action research to inform instructional decision making.

The material in this expertise test covers pedagogical and professional competencies. The 2015 teacher know-how test results show half of 2.9 million teachers scored below the national standard (Direktorat Jendral Guru dan Tenaga Kependidikan, 2015). The average teacher competency value obtained was 53.02 and that obtained from respective provinces such as in the Binuang District of Tapin Regency was 54.04 against the set 55 points. Several school teachers obtained competency test scores below the graduation standard, even those who had educator certificates did not attain the expected standards. 
This condition affects student learning outcomes since the teacher targets the completion of the syllabus than ensuring learners understand what is being taught. It is further assumed teacher trainees do not master the learning materials and resources hence end up implementing less innovative instructional methods.

It, therefore, implies teachers need to take part in PKB activities to improve their competencies. The test results would then improve, having a positive impact on learner outcomes.

Therefore, it is important to conduct a study, aiming at describing and analyzing the relationship of instructional leadership, continuing professional development, teacher work motivation, with the results of elementary school teacher competency test.

\section{Material and Methods}

This research is quantitative with the aid of statistical formulas. The method used is correlational, which describes the relationship contained between two or more variables by probing how strong they relate. The sample table developed by Krejcie and Morgan were used to obtain a total of 120 teachers from the sample of 172 (Sugiyono, 2008).

This research is categorized into a descriptive study, for describing the variables, to predict the closeness of their relationship. The purpose of this study was to determine the relationships contained in; instructional leadership $\left(X_{1}\right)$, continuous professional development $\left(\mathrm{X}_{2}\right)$, work motivation $\left(\mathrm{X}_{3}\right)$, and the results of competency tests (Y).

The relationship between variables in research is described in the following scheme:

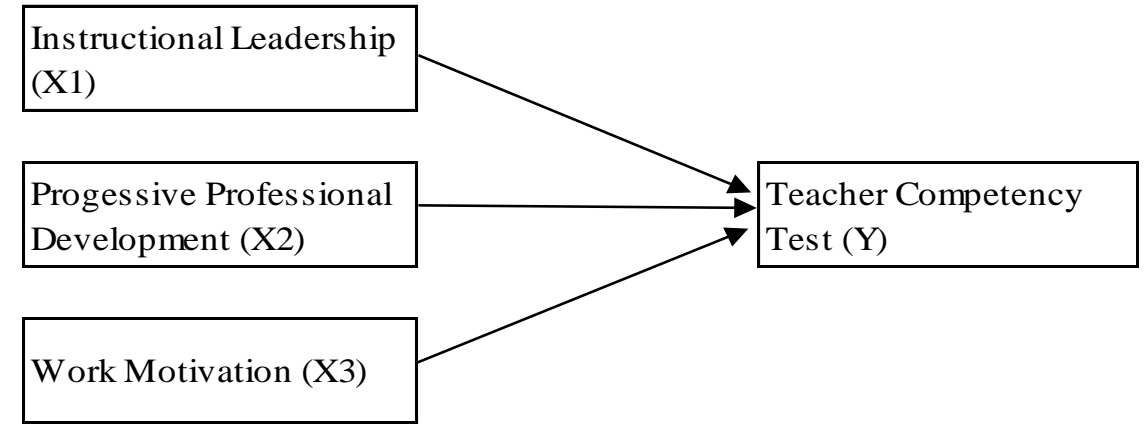

Figure 1. Path Analysis

The size of people used is 172 from 22 schools in Binuang District with a sample group of 120 by proportional random selection. Slovin formula was applied in determining the sample size:

$$
N=\frac{N}{N d^{2}+1}
$$

The data collection technique used was a questionnaire.

\section{Results and Discussion}

The results of the instructional leadership questionnaire showed, the highest score of 120 respondents was 310 (the highest possible is 490), and the lowest score achieved was 140 (the lowest possible is 70 ). The average score of instructional leadership $\left(\mathrm{X}_{1}\right)$ was 244,750, while the median was 278.00 , mode 280 , and the standard deviation 52.996. Based on only 8 respondents rate highly (6.67\%), 72 moderately $(60.00 \%)$ and 40 scored lowly (33.33\%). Therefore, a majority of $60 \%$ of the respondents assess leadership learning with moderate criteria. The results of continuing professional development (PKB) show, 110 was the highest score achieved (of the possible high of 125), while 76 was the lowest achieved (of the possible low of 25). Continuous professional development averaged at 89.36, the median was 91 , mode 94 and the standard deviation was 8.87. The results of the analysis of professional development are explained, the number of respondents who undertake these activities with high criteria is 21 or $17.50 \%$, with the medium of 66 respondents or $55.00 \%$, and 33 inactive or $(25.50 \%)$. From these 
results, $55.00 \%$ of teachers carry out professional development activities.

Results on work motivation show, the highest score achieved by the respondents are 199 (highest possible score is 200), while 137 is the lowest attained (the lowest possible score is 40 ). The mean score of this variable was 163.16 with a median of 157.00 , mode 142 , and a standard deviation of 17.355. a total of 16 respondents $(13.33 \%)$ have a high work motivation, 85 (70.84\%) have moderate, and $19(15.83 \%)$ with a low measure. Therefore, a majority of the teachers have work motivation with a medium value of 85 people or $70.84 \%$. Teacher Competency Test score scores indicate, the highest score achieved by 120 respondents is 81.8452 , while the lowest value achieved was 28.5714. The mean of the variable was 56.1905 , the median 56.5476, mode 61.0119, and the standard deviation 12.5364. From the statistics, 18 respondents $(15.00 \%)$ had a high rating, with a moderate measure, 76 (63.33\%) and 26, (21.67\%) with a low measure. Therefore, most of the teachers have a competency test with moderate criteria with $63.33 \%$.

\section{Instructional Leadership with Teacher Com- petency}

Leadership aims at developing a productive and satisfying work environment for teachers, and to create improved student learning conditions. It emphasizes on the components which are closely related to learning, including curriculum, teaching and learning process, assessment, test, teacher development, and the society. Therefore, the principal needs to improve teacher competency through various science development activities. based on the analysis obtained the average score of instructional leadership is 244.750 with moderate criteria. Raw scores of each subvariable of five, the curriculum has the highest rating of 3.953 with the lowest margin for teacher development at 3.224.

The results of the correlation analysis of instructional leadership independent with dependent variables, the teacher competency test results with a correlation index of 0.753 and with a significance level of $5 \%$. Based on the results of the analysis, there was a significant relationship between instructional leadership and the results of teacher competency tests (UKG). Therefore, the null hypothesis (Ho) "there is no relationship between instructional leadership and teacher competency test results" is rejected, meaning, the proposed (Ha) "there is a relationship between instructional leadership and teacher competency test results" is accepted. Competency according to Nijveld et al. is the combination of knowledge, effort, and experience which enable an individual to complete a task perfectly.

This finding concurs with the outcome of Khan et al. (2009) that instructional leadership means very little unless leaders are willing and able to observe teachers, offer advice about problems and make formative evaluations that support and pinpoint areas to improve. Principals have a responsibility to help teachers, improve the practice, and to hold them accountable for meeting their commitments to teaching and learning. Another research by Ismail et al. (2018) findings between school leaders' instructional leadership impacts teachers' functional competency, especially in teachers' knowledge dimension. For the aspects of teachers' functional competency, teachers' skill dimensions. These results show that teachers' skills are very important and are much more needed for a teacher to have high functional competency.

\section{Continuing Professional Development with The Results of Teacher Competency Tests}

Continuing professional development (PKB) is a form of continuous learning for teachers and is important in making the desired changes in student success. In theory, Seyfarth stated, PKB is an opportunity given to teachers, other professionals, and support personnel to gain new knowledge and attitudes, which would lead to changes in behavior, hence enhancing achievement. Based on the results of the research, the PKB score had an average score of 89.67 with moderate criteria. This CLA consists of 3 sub-variables such as self-development, scientific publications, and innovative work. Selfdevelopment has the highest score of 4.137 while the sub-variable of innovative work has 
the lowest average of 3.074. The results of the correlation analysis between the continuing professional developments with the teacher competency test showed an index of 0.403 with a significance level of $5 \%$.

Based on the results of the analysis, there is a significant relationship between continuing professional development with the results of teacher competency tests. This result found as well as the report of Shaffer and ThomasBrown (2015) that fundamental to the coteaching professional development (CoPD) model is teamwork and the acknowledgment of the roles and that the general education social studies teacher has content knowledge and the veteran special education teacher has expertise in pedagogy. Therefore, the null hypothesis (Ho), "there is no relationship between continuous professional development (PKB) and teacher competency test results" is rejected, it means, the hypothesis proposed (Ha) "there is a relationship between sustainable professional development (PKB) and outcomes teacher competency test" is accepted. Professional development needs to be conducted since teachers are a determinant of the realization of the quality of education in schools. Teachers who have good experience and performance have a significant influence on the progress of students. Conversely, if teachers lack quality, student progress is also hampered.

Therefore, teachers are required to develop their profession continuously become professional. The ability and willingness of teachers are required to realize the success of professional development as regulated by the Minister of State for Administrative Reform. With professional development, especially innovation work, teachers are expected to update their knowledge and increase the value of competency tests. Furthermore, the findings are following the results of the research conducted by Kabilan (2004) that has distinctive implications for teachers, school administrators, and teacher educators who venture into Online Professional Development (OPD) programs. The teachers with varied options of empowering themselves with five aspects of teacher competencies that benefited teacher: motivation, skill, knowledge and ideas, self-directed learning, interactive competence, and computer technology.

\section{Work Motivation with Teacher Competency}

According to Maslow (Siagian, 2004), motivation is an internal driving force that causes people to strive for something to fulfill their needs. Explained by Gibson, it is a concept used to describe the impulses arising on or within an individual in moving and directing behavior. Luthans stated that motivation $h$ starts from a feeling of lack or physiological or psychological needs that activate a behavior or movement aimed at achieving a goal or stimulus.

From the results of the research, the teacher's work motivation has an average score of 163,008 . Among the five sub-variables, selfesteem had the lowest average score of 3.053, while the highest measure was obtained for the social needs which were 4,482. Implying, the teacher feels, they do not have the right to be valued for work performance, respected, get recognition of ability and expertise. Furthermore, there was a significant relationship between teacher work motivation and teacher competency test results. Hoy and Miskel (1996) stated that most teachers had the motivation to learn because teachers had the interest and responsibility to educate students.

Therefore, the null hypothesis (Ho), there is no relationship between work motivation and competency test is rejected. It means, the hypothesis proposed (Ha), there is a relationship between work motivation and teacher competency test is accepted. Maslow's theory stated that people in power fulfill physiological basics needs before directing behaviors to meet higher needs (selfrealization). Lower needs or basic needs to be fulfilled first before higher needs. According to Maslow, fulfilled needs provide motivation. The intensity of a particular need reduces as it gets fulfilled, and the second one in line takes the priority (Siagian, 2004). Reports based on the result are in line with the research study in Pakistan by Aziz et al. (2014) that have a significant positive correlation between teacher 
competencies and motivation of all the teachers. This correlation indicates that teachers with higher competencies also tend to show more motivation. Teachers can improve their performance by accelerating their competencies and motivation. Another research by Mustafa and Othman (2010) the result showed, motivation of Pekanbaru State Senior High School teacher had positive and significant correlation. Work motivation was very important to improve work performance. The teacher's prosperity and work environment should be maintained to improve work performance.

\section{Instructional Leadership, Continuous Profes- sional Development, Work Motivation with Teacher Competency}

From the analysis using multiple correlations between Instructional leadership variables $\left(\mathrm{X}_{1}\right)$, continuous professional development $\left(\mathrm{X}_{2}\right)$, and teacher work motivation $\left(\mathrm{X}_{3}\right)$ with the teacher competency test results $(\mathrm{Y})$, the correlation index is 0.868 with a significance level of $5 \%$. Therefore, there is a significant relationship between instructional leadership, continuous professional development (PKB), work motivation, and teacher competency test. The significance of the relationship is tested by comparing the value of Fcount with Ftable. The criterion Ho is rejected or $\mathrm{Ha}$ is accepted in case the value of Fcount $>F$ table, with a value of $p$ $<0,000$.
The results of the analysis using the SPSS program version 15.00 shows that the $F$ test value of Fcount was $118.550>$ Ftable $=8.54$ and sig 000 . This means that the value of $F$ is very significant in proving the relationship between the independent and the dependent variable. This means there is no relationship between instructional leadership, continuous professional development (PKB), work motivation and teacher competency test, and therefore Horejected. Also, the proposed hypothesis (Ha) "there is a relationship between instructional leadership, sustainable professional development (PKB), work motivation, and teacher competency test " is accepted. To improve the competency test results, motivation is necessary. Motivation can be achieved because of internal factors) and external factors.

This research finding is parallel to Calik et al, (2012) in Turkey research's there were significant relationships between dimensions of instructional leadership and teacher's self-efficacy. It is seen that the highest level of relationship was between evaluating the teaching process and students, a dimension of instructional leadership, and teachers' self-efficacy for using instructional strategies. As this result, it can be asserted that the self and collective efficacy of teachers increase depending on the instructional leadership they perceive.

Table 1. Multiple Correlation Analysis

\begin{tabular}{|c|c|c|c|c|c|c|c|c|c|}
\hline \multirow{2}{*}{$\begin{array}{c}\text { R } \\
\text { Square } \\
\text { Change }\end{array}$} & \multirow[t]{2}{*}{$\mathbf{R}$} & \multirow[t]{2}{*}{$\begin{array}{c}\mathbf{R} \\
\text { Square }\end{array}$} & \multicolumn{2}{|c|}{$\begin{array}{l}\text { Adjusted R } \\
\text { Square }\end{array}$} & \multicolumn{2}{|c|}{$\begin{array}{c}\text { Std. The error of the Es } \\
\text { timate }\end{array}$} & \multicolumn{3}{|c|}{ Change Statistics } \\
\hline & & & df1 & df2 & $\begin{array}{c}\text { Sig. F } \\
\text { Change }\end{array}$ & $\begin{array}{l}\text { R Square } \\
\text { Change }\end{array}$ & F Change & df1 & df2 \\
\hline 1 & $.868(a)$ & 0.754 & 0.748 & 6.231 & .754 & 118.550 & 3 & 116 & .000 \\
\hline
\end{tabular}

a Predictors: (Constant), Motivation, PKB, Instructional leadership

b Dependent Variable: UK

The results of the analysis, it was found that the $\mathrm{F}$ test value of Fcount was 118.550> Ftable $=8.54$ and sig 000. This means that the $\mathrm{F}$

value obtained and significant to prove the relationship between the independent variables and the dependent variable. 
Table 2. ANOVA(b)

\begin{tabular}{ccccccc}
\hline & & Sum of & & & Mean \\
Squares & df & Square & F & Sig. \\
\hline 1 & Regression & 13808.845 & 3 & 4602.948 & 118.550 & $.000(\mathrm{a})$ \\
\hline & & & & & \\
& Residual & 4503.955 & 116 & 38.827 & & \\
\hline & & & & & \\
\end{tabular}

a Predictors: (Constant), Motivation, PKB, Instructional leadership

b Dependent Variable: UKG

This means that the hypothesis (Ha): "there is a relationship between Instructional Leadership, Progressive Professional Development, Work Motivation, and the Assessment Results

\section{Conclusion and Recommendation}

This research is expected to be used as information and evaluation material for teachers who are civil servants in carrying out their duties and responsibilities. It could also be helpful as feedback for refinement and improvement of the ability and quality of teacher the school principal. Also, it is a good material for school principals to foster teachers in schools. With good guidance, it is expected; teachers can increase knowledge and insight, to become more informed hence, improving student scores. Furthermore, the document could be used as information material which determines the improvement areas needing more attention. especially, those with professional training certificates to improve the ability and quality of competencies. Therefore, the value of learning will be achieved and could be a reference material for future researchers.

\section{Acknowledgment}

The authors are grateful to all elementary teachers in Binuang District, Tapin Regency, and Education Management Master Program, Universitas Lambung Mangkurat for their support and assistance in carrying out this research.

\section{References}

Aziz, F., Akhtar, M. S., \& Rauf, M. (2014). Relationship between teachers' competencies and motivation at higher education level in Pakistan. Pakistan Annual Research Journal, 50(1), 163-174.

Calik, T., Sezgin, F., Kavgaci, H., \& Klinic, A. C. (2012). Examination of relationship berween instructional leadership of school principals and self-efficacy of teachers and collective teacher efficacy. Educational Science: Theory \& Practice, 12(4), 2498-2504.

Direktorat Jendral Pendidikan Nasional Guru dan Tenaga Kependidikan. (2015). Laporan Sementara Hasil UKG. Direktorat Jenderal Pendidikan Nasional : Jakarta.

Gambone, M. A. (2017). Teaching the possible: Justice-Oriented professional development for progresssive educators. Brock Education: A Journal of educational Research and Practice ,27(1), 53-66. doi:10.26522/BROCKED.V27I1.625

Hallinger, P. (2010). Developing instructional leadership. Educational Leadership, 45(1), 54-61. doi:10.1007/97890-481-9106-2_5

Hoy, W. K., \& Miskel, C. C. (1996). Educational Administration: Theory, Research and Practice. New York: McGraw-Hill Book.

Ismail, S. N., Don, Y., Husin, F., \& Khalid, R. (2018). Instructional leadership and teacher's functional competency across the 21st century learning. International Journal of Instruction, 11(3), 135-152. doi:10.12973/iji.2018.11310a

Kabilan, M. K. (2005). Online Professional Development: a literature analysis of teacher competency. Journal of Computing in Teacher Education, 21(2), 51-57.

Khan, Z., Khan, U. A., Shah, R. U., \& Iqbal, J. (2009). Instructional leadership, supervision and teacher development. Dialogue, 4(4), 580-592.

Labaree, D. F. (2005). Progressivism, Schools and Schools of Education: An American Romance. Paedagogica Historica, 41(1\&2), 275-288. doi:10.1080/0030923042000335583

Mustafa, M. N., \& Othman, N. (2010). The effect of work motivation on teacher's work performance in Pekanbaru Senior High Schools, Riau Province, Indonesia. Sosiohumanika: Jurnal Pendidikan Sains Sosial dan Kemanusiaan, 3(2), 259-272. doi:10.2121/sosiohun 
Shaffer, L., \& Thomas-Brown, K. (2015). Enhancing teacher competency through co-teaching embedded professional development. Journal of Educational and Training Studies, 3(3), 117-125. doi:10.11114/jets.v3i3.685

Siagian, S. P. (2004). Manajemen sumber daya manusia. Jakarta: Bumi Aksara.
Soutworth, G. (2002). Instructional leadership in school: reflection and empirical evidence. Journal School Leadership and Management, 22(1), 73-92. doi:10.1080/13632430220143042.

Sugiyono. (2008). Penelitian kuantitatif, kualitatif dan R\&D. Bandung: Alfabeta. 